\title{
MICROMORPHOLOGY OF Rosa rugosa Thunb. PETAL EPIDERMIS SECRETING FRAGRANT SUBSTANCES
}

\author{
Aneta Sulborska, Elżbieta Weryszko-Chmielewska, Mirosława Chwil \\ Department of Botany, University of Life Sciences, Akademicka 15, 20-950 Lublin, Poland \\ e-mail: aneta.sulborska@up.lublin.pl
}

Received: 12.07.2012

\begin{abstract}
The intensely fragrant flowers of the Rosa rugosa Thunb. have been applied in medicine, and food and cosmetic industries. The species is cultivated for production of rose essential oil (Oleum Rosae) from its flowers. R. rugosa petals secrete the largest quantities of essential oil.

The aim of the study was to identify the characteristics of the epidermis of both sides of the petal and to observe whether adaxial and abaxial epidermal cells can secrete essential oil. The investigations were conducted using light and scanning electron microscopy. The analyses were focused on petal thickness and characteristics of the mesophyll. The study has demonstrated that only adaxial epidermal cells form conical papillae covered by massive cuticular striae. The surface of the papillae displayed remnants of a secretory substance. In turn, the inner walls of the abaxial epidermal cells were flat and covered by a striated cuticle, which exhibited various striation patterns. Fragrant substances stored under the cuticle caused local stretching thereof and disappearance of striation. The results of our observations allow a statement that the cells of the adaxial and abaxial epidermis of $R$. rugosa petals differ in terms of the structure and they secrete fragrant substances.
\end{abstract}

Key words: Rosa rugosa, petals, epidermis, papillae, cuticle, secretory products, SEM.

\section{INTRODUCTION}

Rosa rugosa Thunb. originates from north-eastern Asia (S zweykowska and Szweyk ow ski, 2003; Bru un, 2005). It was introduced in Europe as an ornamental plant in the mid- $19^{\text {th }}$ century (B r u u n, 2006). $R$. rugosa is a $1-2 \mathrm{~m}$ high shrub characterized by vegetative reproduction by root suckers. Its large red-pink flowers $6-12 \mathrm{~cm}$ in diameter are single form clusters of 3-6 ( $\mathrm{S} \mathrm{z} \mathrm{we} \mathrm{y} \mathrm{k} \mathrm{ow} \mathrm{s} \mathrm{ka}$ and Szweykowski, 2003). In the Polish condi- tions, the species flowers between May and September (Rutkowski, 2008).

Rosa rugosa has modest soil requirements and is characterized by considerable frost and draught resistance. Since the beginning of the $20^{\text {th }}$ century, the species has been planted along roads, reinforcement of sandy slopes, railway embankments, and coastal dunes in Europe and North America ( $\mathrm{S}$ z w e y k o w ska and Szweykowski, 2003; B ruun, 2005, 2006). In its homeland (China), Rosa rugosa is regarded as a rare species, whereas in the localities where it has been introduced, i.e. North America, Europe, and Australia, it is an invasive plant (M a rinelli, 2006). Indications of $R$. rugosa invasion have been reported from many European countries: the British Isles, the Netherlands, Germany, Denmark, Norway, Sweden, and Lithuania (B r u u n, 2005; 2006). Seed dispersal through water contributes to intensive colonization of the coasts e.g. in the Scandinavian countries (B r u u n, 2005). Additionally, seeds can be dispersed by birds and small mammals (B ru un, 2005; Marinelli, 2006).

R. rugosa fruits contain substantial amounts of vitamin $\mathrm{C}$ and are therefore used for production of food concentrates. Rose petals are used for production of confitures and jellies ( $\mathrm{S} \mathrm{zw}$ e y k ow s k a and S zwe y kowski, 2003). Thanks to its aromatizing properties, rose oil (Oleum Rosae) is used not only in cosmetic and food industries, but also in pharmaceutical industry as an additive to improve the flavour and smell of drugs and as an appetite stimulant (Kohl$\mathrm{münzer}, 1998)$. $R$. rugosa is grown in Asia as an oil-bearing plant (Feng et al. 2010). Dry petals and buds of $R$. rugosa are used as a multiple-action drug in the traditional Chinese medicine and as raw material for herbal tea production (O c h i r et al. 2010). 
The flower scent is primarily emitted by petals (B r u u n, 2005). Anatomical and chemical analyses have revealed significant differences between odourless petals and scent-emitting petals of Rosa x hybrida varieties. Age-related development of petal tissues of Rosa $x$ hybrida flowers has also been described (B e r g o u g n o u x et al. 2007). Histochemical and chromatographic analyses performed by the above-mentioned authors demonstrate that both the adaxial and abaxial surface of rose petals produce and secrete similar quantities of fragrant substances with a similar chemical composition. In turn, D o b s o n et al. (1990) have found that different parts of the Rosa rugosa flower, i.e. petals, sepals plus gynoecium, anthers, and pollen, produce fragrant substances differing in terms of their chemical composition.

The aim of our study was to compare the micromorphology of the adaxial and abaxial epidermis of $R$. rugosa petals in fully developed scent-emitting flowers. Additionally, petal thickness and mesophyll characteristics were determined.

\section{MATERIAL AND METHODS}

The flowers of Rosa rugosa Thunb. were taken from the shrubs growing in the collection of the of Maria Curie-Skłodowska University Botanical Garden in Lublin.

Preliminary observations of the structure of petals in the corolla of fully open flowers were performed using light microscopy. To this end, cross sections of the petals were manually prepared.

The micromorphology of the adaxial and abaxial epidermis of petals and their cross sections were analyzed with the use of scanning electron microscopy (SEM). Fragments of petals were fixed in $4 \%$ glutaraldehyde in $0,1 \mathrm{M}$ phosphate buffer ( $\mathrm{pH} 7,0)$. Next, they were dehydrated in ethanol and an acetone series. In a subsequent stage, the plant samples were critical-point dried in liquid $\mathrm{CO}_{2}$ and sputter-coated with gold using a CS 100 Sputter Coater. The observations and photographic documentation were performed using a Tescan Vega II scanning electron microscope.

\section{RESULTS}

\section{General characteristics of petal tissues}

Relatively thin layers of the adaxial and abaxial epidermis and mesophyll covering a considerable part of the petal were visible in the cross section of the Rosa rugosa petal (Fig. 1 B). The petal thickness is $110-120 \mu \mathrm{m}$ in the central part. On a large area of the petal, the adaxial epidermis cells form conical papillae, which do not occur in the basal part of the organ only. In turn, the abaxial epidermis consists of cells with flat outer walls (Fig. 1 B, G). The pink colour of the petals is provided by anthocyanin contained in the vacuoles of cells of both the epidermal layers. The petal mesophyll is composed of multiple layers of parenchymal cells separated by very large intercellular spaces. The cells are irregularly branched and form "arm-like appendages" (Fig. 1 B, C, D). The vascular system of the petal consists of several large and numerous much smaller nerves made up of collateral bundles (Fig. 1 D). The xylem of the vascular bundles contains mainly spiral vessels, fragments of which were observed in the petal tissue (Fig. 1 E).

\section{Adaxial epidermis}

The height of the cells in this tissue ranges from 28 to $32 \mu \mathrm{m}$. The outer walls are strongly convex and form conical papillae (Figs 1 F; 2 D, E), whereas the anticlinal walls are straight (Fig. 2 B). The upper part of the papillae is covered by massive cuticular striae converging at the apex (Fig. $2 \mathrm{~A}-\mathrm{F}$ ). The maximum width of the striae is ca. $1 \mu \mathrm{m}$. Striation is also visible in the inner part of the papillae-forming wall (Fig. 1 F).

Conspicuous convexities of the cuticle, probably caused by accumulation of the secretion, were found in the apical part of some papillae (Fig. 2 D). Remnants of the secretory substance were visible on the surface of the papillae in many parts of the epidermis (Fig. 2 B, C, D).

\section{Abaxial epidermis}

This epidermal layer is formed by cells with flat outer walls producing no papillae. The surface of the cuticle covering tangential walls is striated and is characterized by diverse striation patterns. The striae are parallel in some parts, while in others they form irregular clusters and folds (Fig. 3 A-D). The approximate thickness of the striae is $1 \mu \mathrm{m}$. The arrangement of the massive and dense cuticular striae masks the boundaries between individual cells and prevents assessment of their shapes.

In the central part of the petal, we observed circular or oval-shaped surfaces with a smooth cuticle probably formed by stretching of the striae by the secretory substance accumulating under the cuticle (Fig. 3 A, B, D). The secretory activity of some epidermal areas resulted in accumulation of substantial amounts of secretion under the cuticle, the surface of which lost its original striation due to stretching (Fig. 4 A-D). The observations of the abaxial surface of the epidermis of various petal fragments indicate that the process of secretion did not proceed synchronously. No stomata were found in the abaxial epidermis of the petal. 

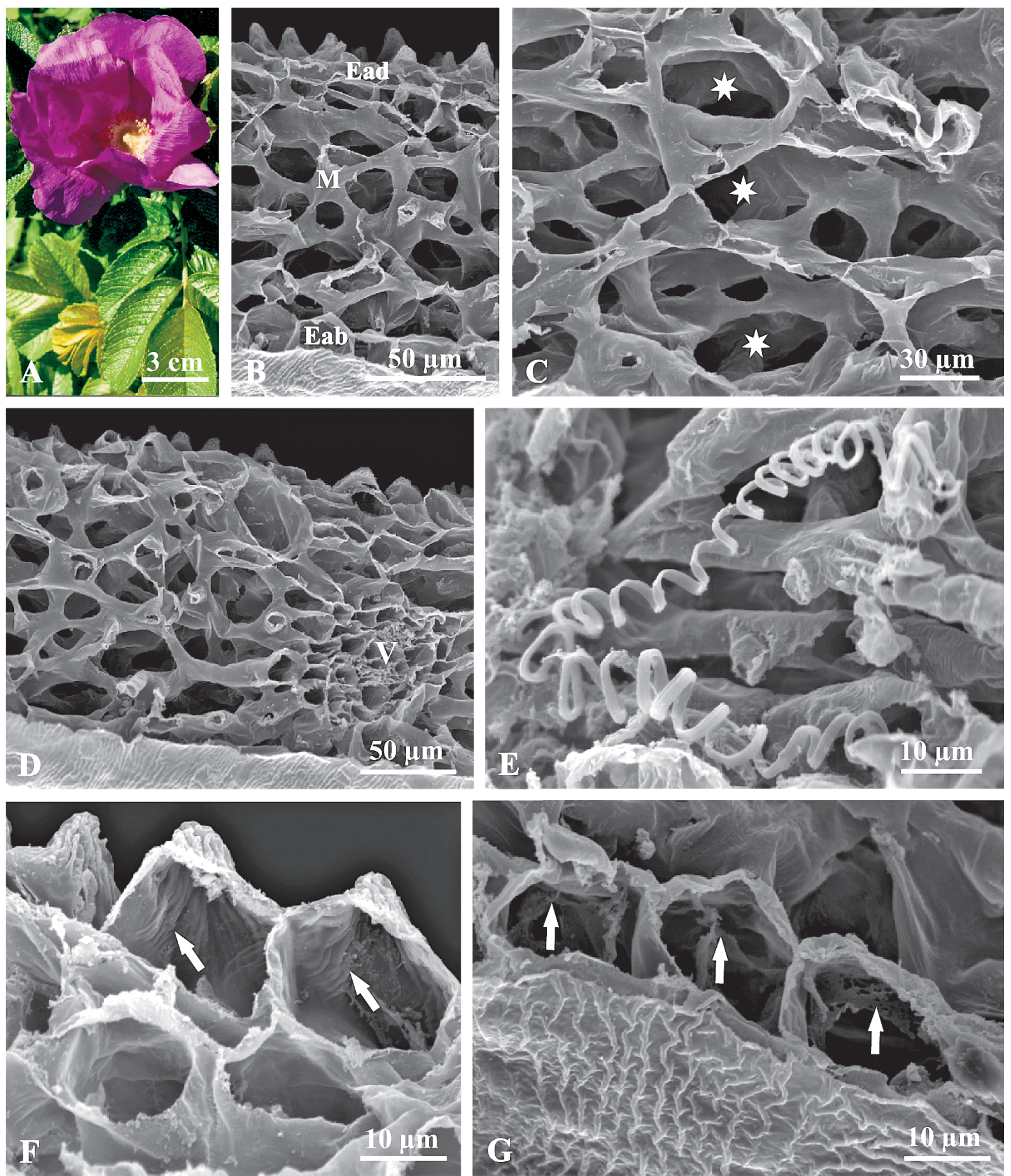

Fig. 1. Fragment of the Rosa rugosa plant and petal tissue (SEM).

A. General structure of the flower and leaves.

B. Fragment of the petal cross section; Ead - adaxial epidermis, Eab - abaxial epidermis, M - mesophyll.

C. Fragment of the petal mesophyll with characteristically branched "arm-like" cells and large intercellular spaces (asterisks).

D. Fragment of the petal cross section with a visible vascular bundle (V).

E. Fragment of the petal with visible spiral reinforcements of the protoxylem vessels.

F. Fragment of the cross section of the adaxial epidermis. Visible papillae with undulated inner cell wall (arrows).

G. Fragment of the cross section of the abaxial epidermis. Remnants of protoplasts visible inside the cells (arrows). 



Fig. 2. Surface of the adaxial epidermal cells in Rosa rugosa (SEM).

A-F. Fragments of epidermis with visible papillae. B, C, D, F - the arrows indicate remnants of the secretory substance. $\mathrm{D}$ - Convexity of the cuticle resulting from the presence of the secretion is visible in the apical part of some papillae (arrowheads). 

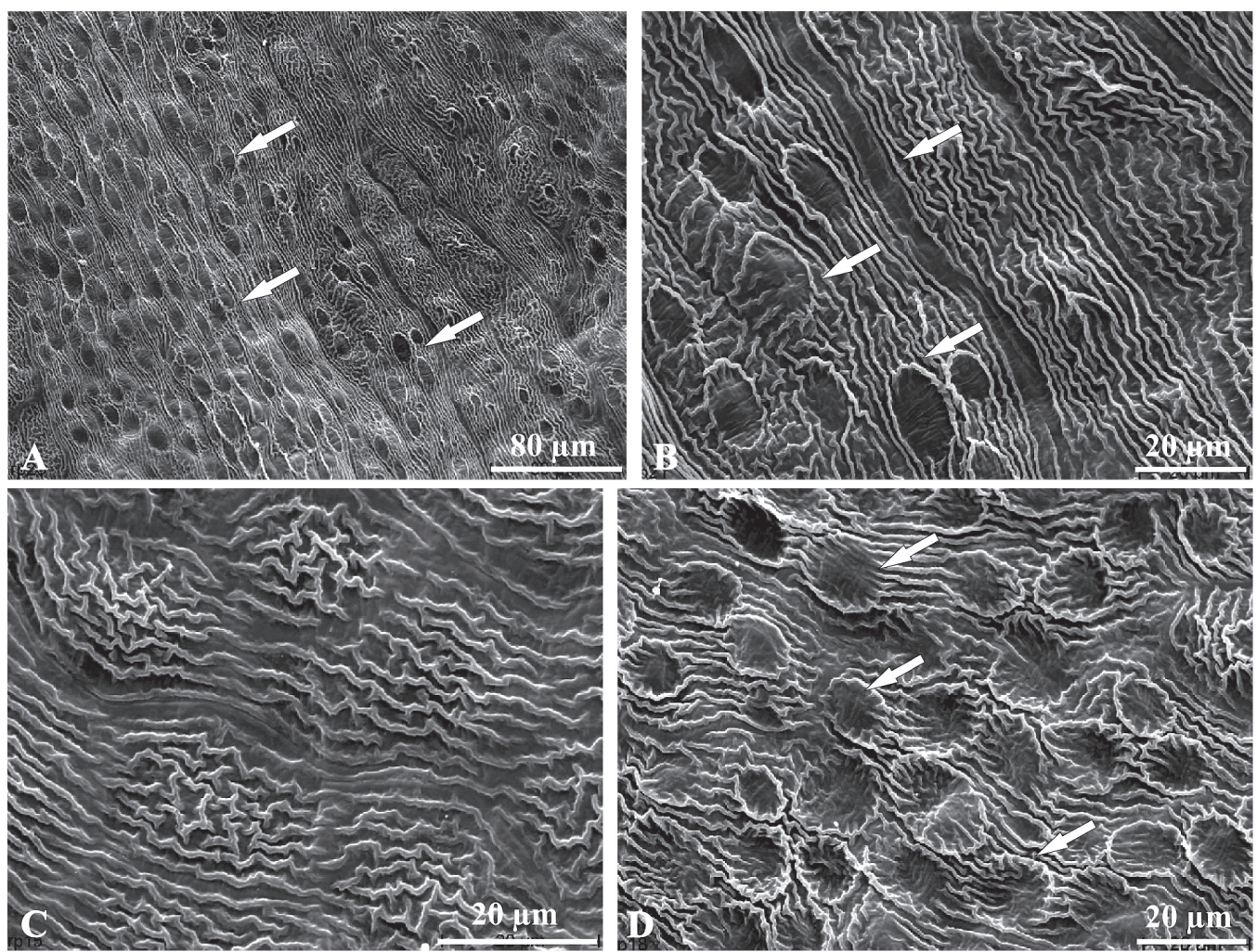

Fig. 3. Surface of the abaxial epidermal cells in Rosa rugosa (SEM).

A-D. Fragments of epidermis with characteristic cuticular ornamentation. A, B, D - visible circular and oval-shaped areas with a smooth cucticle (arrows).
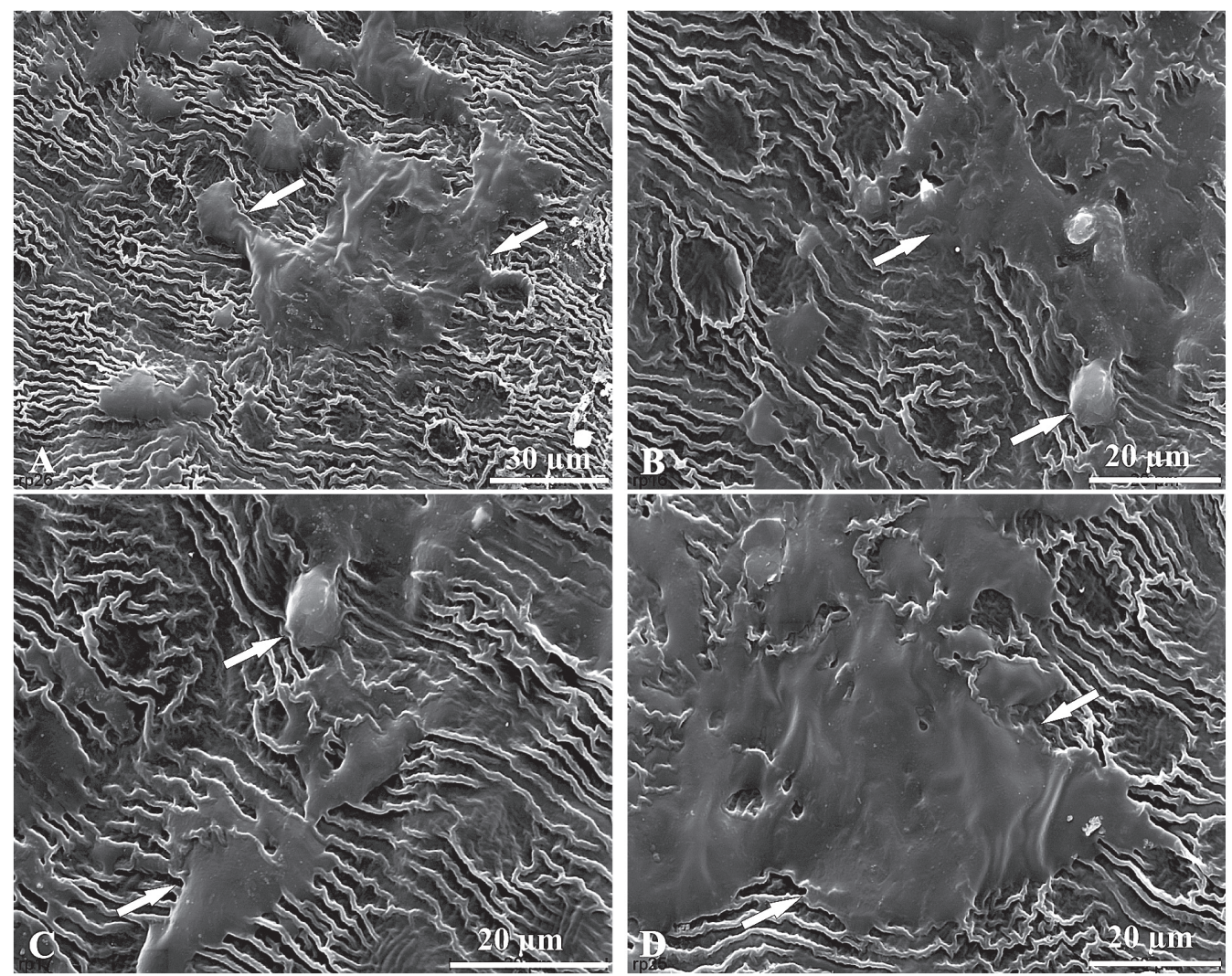

Fig. 4. Surface of the abaxial epidermal cells in Rosa rugosa (SEM).

A-D.Fragments of epidermis with visible secretion stored under the smooth cuticle (arrows). 


\section{DISCUSSION}

Essential oils are contained primarily in petal epidermal cells or in flower parts differentiated into osmophores (E s a u , 1973; V o g e 1, 1990). We have found that fragrant substances in Rosa rugosa petals are secreted by the cells of both the adaxial and abaxial epidermis. Our results confirm the results of previous investigations conducted on Rosa $x$ hybrida by B e rg o u g n o ux et al. (2007), who demonstrated a similar degree of secretory activity in the adaxial and abaxial epidermis of petals.

Similarly to Rosa $x$ hybrida petals (B e r g o u g n o u x et al. 2007), papillae were found only in the adaxial epidermis in the Rosa rugosa petals in our study. Essential oil was secreted by the apical part of the papillae covered by multiple cuticular striae. The secretory activity of the papillae was asynchronous. Convexities of the cuticle filled with the secretion were observed in the apical part of some papillae only. In other papillae, the remnants of the secretory substance were dispersed on the surface of cell walls. A majority of the papillae observed in the petals were probably in the pre-secretory stage.

Secretion of essential oil from flowers of various Rosa species is closely associated with the pollination biology. Rose flowers attract insects through their colour and scent. Pollen is the only reward for pollinators, as Rosa flowers do not produce nectar. In Europe, insects that pollinate the flowers of $R$. rugosa include Lasioglossum, a few species from the genus Bombus, and Apis mellifera (B r u u n, 2005). The major components of $R$. rugosa fragrance are citronellol, geraniol and nerol, and over 10 other monoterpenes, each of which constitutes more than $0.05 \%$ of the relative amount (H a s h i d o k o, 1996).

It has been suggested that papillae formed by the adaxial epidermis in petals of many plant species can serve various functions (W hitne y et al. 2009, 2011). They occur primarily in the flowers of entomophilous plants and may facilitate pollinator grip in the flower. Papillae have been found to exert an effect on the intensity of petal colour and petal reflexing. They also contribute to scent production, petal wettability, and to some extent faster warming of the petal. Among the 201 entomophilous plant species examined, 79\% exhibited presence of papillae in the adaxial epidermis (K a y et al. 1981). Absence of papillae in epidermal cells of Petasites petals ( $\mathrm{H}$ arat y $\mathrm{m}$ and $\mathrm{W}$ e r y s z $\mathrm{k} \mathrm{o}-\mathrm{Chmi}$ ele w s k a, 2012) and in the epidermis of Galanthus tepals (Weryszko-Chmielewska and $\mathrm{Chwi}$, 2010) was reported in our previous papers.

A characteristic feature of the epidermis of many plant species is occurrence of striated cuticle forming specific patterns. It has been shown that cuticle stretching and spread of initial folds along the epidermal cell surface is possible (E s a u , 1973). Similarly, $R$. rugosa displayed local alterations in the arrangement of the cuticular striae accompanying the secretory activity. The cuticle is the first protective barrier between the plant surface in contact with air and plant environment; it is also the major barrier against the transpiration stream and different solutions ( $\mathrm{R} \mathrm{i} \mathrm{e} \mathrm{d} \mathrm{e} \mathrm{-}$ rer and Schreiber, 2001; Evert, 2006). Therefore, the cuticle can be assumed to play an important role in secretion of essential oils by the flower petal epidermis. Release of secretory products on the cuticle surface may proceed through cuticular ruptures or pores (A n cen săo and Pa is, 1998; Evert, 2006). As demonstrated by our observations, secretion of essential oil by epidermal cells in $R$. rugosa is accompanied by cuticular stretching and rupture.

We have found that the adaxial and abaxial epidermis in $R$. rugosa secretes essential oil despite the differences in the cell structure. Similar results for $R$. $x$ hybrida were obtained by B e rgoug nou x et al. (2007). Similarly, our previous investigations demonstrated a high diversity in the structure of cells releasing aromatic compound in Asphodelus aestivus filaments (Werys zk o-Ch mi e lew ska et al. 2007).

\section{Acknowledgements}

Research supported by the Ministry of Science and Higher Education of Poland as the part of statutory activities of Department of Botany, University of Life Sciences in Lublin.

\section{REFERENCES}

Ancensăo L., Pais M.S. 1998. The leaf capitates trichomes of Leonotis leonurus: Histochemistry, ultrastructure, and secretion. Ann. Bot. 81: 263-271.

Bergougnoux V., Caissard J-C., Jullien F., Magnard J-L., Scalliet G., Cock J.M., Hugueney P., Baudino S., 2007. Both the adaxial and abaxial epidermis layers of the rose petal emit volatile scent compounds. Planta. DOI 10.1007/s00425007-0531-1.

Bruun H.H. 2005. Biological flora of the British Isles. J. Ecol. 93: 441-470.

Bruun H.H. 2006. Prospects for biocontrol of invasine Rosa rugosa. BioControl, 51: 141-181. DOI 10.1007/ s10526-005-6757-6.

Dobson H.E.M., Bergström G., Groth I. 1990. Differences in fragrance chemistry between flower parts of Rosa rugosa Thunb. (Rosaceae). Israel J. Bot. 39: 143-156.

Es a u K. 1973. Anatomia roślin. Państwowe Wydawnictwo Rolnicze i Leśne, Warszawa. (in Polish)

Evert R.F. 2006. Esau's Plant Anatomy. Meristems, cells, and tissues of the plant body: their structure, function, 
and development. John Wiley \& Sons, Inc. Hoboken, New Jersey.

Feng L-G., Chen C., Sheng L-X., Liu P., Tao J., Su J-L., Zh a o L-Y., 2010. Comparative analysis of headspace volatile of Chinese Rosa rugosa. Molecules, 15, 8390-8399. DOI: 10.3390/molecules 15118390.

Haratym W., Weryszko-Chmielewska E., 2012. The ecological features of flowers and inflorescences of two species of the genus Petasites Miller (Asteraceae). Acta Agrobot. 65(2): 37-46.

Hashidoko Y. 1996. The phytochemistry of Rosa rugosa. Phytochemistry, 43: 535-549. http://dx.doi.org/10. 1016/0031-9422(96)00287-7

Kay Q.O.N., Daoud H.S., Stirton C.H. 1981. Pigment distribution, light reflection and cell structure in petals. Bot. J. Linn. Soc. 83: 57-83. http://dx.doi.org/10.1111/j. 1095-8339.1981.tb00129.x

Kohlmünzer S . 1998. Farmakognozja. Podręcznik dla studentów farmacji. Państwowe Zakłady Wydawnictw Lekarskich, Warszawa. (in Polish)

Marinelli J. 2006. Wielka Encyklopedia Roślin. Świat Książki, Bertelsmann Media sp. z o.o., Warszawa. (in Polish)

Ochir S., Ishii K., Park B., Matsuta T., Nishizawa M., Kanazawa T., Funaki M., Yamagishi T. 2010. Botanical origin of Mei-giu Hua (petal of Rosa species). J. Nat. Med. 64: 409-416.

Riederer M., Schreiber L. 2001. Protecting against water loss: Analysis of the barrier properties of plant cuticles. J. Exp. Bot. 52: 2023-2032. http://dx.doi.org/10. 1093/jexbot/52.363.2023

Rutkowski L. 2008. Klucz do oznaczania roślin naczyniowych Polski niżowej. Państwowe Wydawnictwo Naukowe, Warszawa. (in Polish)

Szweykowska A., Szweykowski J. 2003. Słownik botaniczny. Wiedza Powszechna, Warszawa. (in Polish)

Vogel S. 1990. The role of scent glands in pollination. The National Science Foundation, Washington, D.C.

Weryszko-Chmielewska E. Chwil M. 2010. Ecological adaptations of the floral structures of Galanthus nivalis L. Acta Agrobot. 63 (2): 41-49.

Weryszko-Chmielewska E., Chwil M., Sawidis T. 2007. Micromorphology and histochemical traits of staminal osmophores in Asphodelus aestivus Brot. flower. Acta Agrobot. 60 (1): 13-23.
Whitney H.M., Chittka L., Bruce T.J.A., Glove r B . J . 2009. Conical epidermal cells allow bees to grip flowers and increase foraging efficiency. Curr. Biol. 19: 948-953. http://dx.doi.org/10.1016/j.cub.2009.04.051

Whitney H.M., Bennett K.M.V., Dorling M., Sandbach L. Prince D., Chittka L., Glover B.J. 2011. Why do so many petals have conical epidemis cells? Ann. Bot. 108: 609-616.

\section{Mikromorfologia epidermy płatków Rosa rugosa Thunb. wydzielającej substancje zapachowe}

\section{Streszczenie}

Intensywnie pachnące kwiaty Rosa rugosa Thunb. znalazły zastosowanie w lecznictwie, przemyśle spożywczym i kosmetycznym. Dla uzyskania olejku różanego (Oleum Rosae) z kwiatów prowadzone są uprawy krzewów tego gatunku. Najwięcej olejku emitują płatki $R$. rugosa.

Celem badań było określenie charakterystycznych cech epidermy obu stron płatka oraz stwierdzenie, czy komórki adaksjalnej i abaksjalnej epidermy mogą emitować olejek eteryczny. Badania przeprowadzono przy zastosowaniu mikroskopii świetlnej i skaningowej elektronowej. Zwrócono uwagę na grubość płatków i cechy charakterystyczne mezofilu. Z badań wynika, że tylko komórki adaksjalnej epidermy tworzą stożkowate papille pokryte masywnymi prążkami kutykularnymi. Na powierzchni papilli obserwowano pozostałości wydzieliny. Natomiast zewnętrzne ściany komórek abaksjalnej epidermy były płaskie, ale również pokryte prążkowaną kutykulą, która wykazywała różne wzory. Gromadzone pod kutykulą substancje zapachowe powodowały lokalne jej rozciąganie i zanik prążkowanych wzorów. Wyniki naszych obserwacji upoważniają do stwierdzenia, że komórki górnej i dolnej epidermy płatków $R$. rugosa różnią się budową i emitują substancje zapachowe. 
